\title{
Novas Tecnologias aplicadas à Formação - um estudo de caso
}

\author{
Alexandra Sousa \\ Agência para a Modernização Administrativa (AMA - LC Setúbal \\ alexandra.sousa@ama.pt \\ João Pedro Cordeiro \\ Escola Superior de Ciências Empresariais \\ Instituto Politécnico de Setúbal \\ joao.cordeiro@esce.ips.pt
}

\begin{abstract}
:
Os desafios colocados aos Recursos Humanos são cada vez maiores. A par da crescente evolução tecnológica e das suas consequências na organização do trabalho, no conteúdo dos empregos e no aumento das qualificações dos trabalhadores, é reconhecida necessidade dos empregadores investirem em mão-de-obra qualificada, para permitir uma maior qualidade e desempenho dos seus recursos humanos. Assim, urge implementar programas de ação destinados a promover a formação profissional contínua, dinamizando a conceção da formação e a modernização na gestão, nas metodologias e nos equipamentos necessários à formação profissional contínua, que respondam à evolução das necessidades de formação. Assiim,o presente estudo centrou-se numa abordagem das novas tecnologias aplicadas à formação em contexto organizacional. O objeto de estudo foram as diferentes entidades pertencentes à Loja do Cidadão de Setúbal, que fazem parte de um serviço descentralizado que integram a AMA - Agência para a Modernização Administrativa. Como objetivos pretendeu-se analisar a importância da formação b-learning enquanto instrumento de desenvolvimento dos trabalhadores nas Lojas do Cidadão. Focar o seu estudo nas modalidades de formação utilizadas no b-learning que permitiram a formação contínua dos funcionários de uma organização que tem os seus serviços descentralizados, existindo a necessidade de se atualizarem para estarem preparados para enfrentar as mudanças que surgem num ambiente de incertezas e mudança contínua. Perceber de que forma as novas tecnologias de informação e comunicação, podeam ser uma ferramenta preponderante quando colocadas à disposição dos trabalhadores na sua formação contínua, para que os mesmos respondam de forma eficiente e eficaz, atendendo à cultura organizacional e padrões de qualidade esperados no âmbito comportamental que lhes é solicitada pela organização. Em termos metodológicos utilizou-se a metodologia qualitativa que pretendeu delinear um processo de investigação do tema anteriormente proposto, ao nível do conhecimento exploratório. Para tal, recorreu-se à metodologia do estudo de caso, a qual pretendeu verificar o impacto registado na organização e nos indivíduos, dos processos de formação e das aprendizagens realizadas. . Para recolha de informação utilizou-se a técnica de entrevista semiestruturada (ao responsável da formação, formador/tutor e formandos das ações), a análise documental e análise de conteúdo de diferentes tipos de documentação produzida pela organização no decorrer das ações. Através dos instrumentos utilizados pretendeu-se aferir se foi efetivamente uma boa decisão estratégica da organização em estudo, a utilização das novas tecnologias, nomeadamente ao nível da introdução da metodologia b-learning na formação contínua dos trabalhadores. Como conclusão, conseguiu-se apurar que existiu uma evolução no contexto cultural e organizacional da organização em estudo, pelo facto de introduzir estrategicamente novas tecnologias de informação e comunicação, através da implementação da metodologia de formação de acções bLearning no ano 2008. Foi criado um departamento de formação (2010) para responder
\end{abstract}


eficazmente às necessidades da mesma, com a introdução de novos cursos, considerando a sua missão, os seus valores e os padrões de desempenho exigidos aos trabalhadores que prestam atendimento ao público, na prossecução dos objetivos da Agência para a Modernização Administrativa em geral e na Loja do Cidadão de Setúbal em particular, no período de 2008 a 2011.

KEYWORDS: Formação Contínua, Metodologias de Formação, b-Learning Tecnologia de informação e comunicação. 